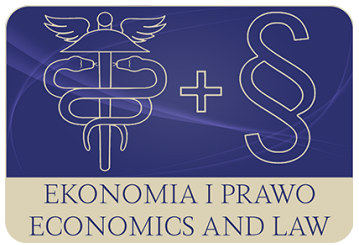

EKONOMIA I PRAWO. ECONOMICS AND LAW

Volume 20, Issue 4, December 2021

p-ISSN 1898-2255, e-ISSN 2392-1625

www.economicsandlaw.pl

ORIGINAL ARTICLE

received 10.07.2021; revised 01.12.2021; accepted 31.12.2021

Citation: Kaya, M.V., Yılmaz, S.S., \& Özdemir, M.G. (2021). The relationship of economic growth and carbon-dioxide emissions: an application on member countries of Organization of Islamic Cooperation. Ekonomia i Prawo. Economics and Law, 20(4), 813-833. https://doi.org/10.12775/EiP.2021.048.

\title{
The relationship of economic growth and carbon-dioxide emissions: an application on member countries of Organization of Islamic Cooperation
}

\author{
MUHAMMED VEYSEL KAYA \\ Kirikkale University, Faculty of Economics and Administrative Sciences, Turkey \\ $\square$ mveyselkaya@yahoo.com \\ (D) orcid.org/0000-0001-9322-1694 \\ SUAT SERHAT YILMAZ \\ Kirikkale University, Faculty of Economics and Administrative Sciences, Turkey \\ ๑ suatserhatyilmaz@gmail.com \\ (D) orcid.org/0000-0003-2900-0824

\section{MEHMET GÖKHAN ÖZDEMIR} \\ corresponding author \\ Kirikkale University, Faculty of Economics and Administrative Sciences, Besir Atalay Campus, \\ Ankara Yolu 7. Km, 71450 Kirikkale, Turkey \\ $\square$ mgozdemirera@gmail.com \\ (D) orcid.org/0000-0002-6756-7285
}

\begin{abstract}
Motivation: Humanity has benefited from natural resources in production activities throughout history and this pressure on natural resources has increased even more with the efforts of industrialization. In this process, people benefited heavily from fossil fuels in their production and distribution activities, thereby damaging the environment and the atmosphere to a large extent. With the destruction of the environment, it has become important for the countries and the academic circles to measure environmental damage with the increase of economic activities in order to take various measures.
\end{abstract}


Aim: At this point, in this study, the relationship between economic growth and carbon-dioxide emissions was examined within the scope of 50 countries that are mem-

bers of the Organization of Islamic Cooperation (OIC). In this process, annual data of the countries concerned between 1995 and 2017 were used; Pedroni Cointegration Analysis, Granger Causality Analysis, Pooled Mean Group Estimator (PMGE) and Mean Group Estimator (MGE) methods were used to measure and estimate the relationship between these two variables. The causality analysis shows that the economic growth is the Granger cause of carbon-dioxide emissions in the country group studied. In addition, the coefficients obtained in PMGE and MGE analyzes were found as 0.43 and 0.33 and were statistically significant and positive. Then, with the help of Hausman Homogeneity Test, it was decided between the two estimators, and it concluded that PMGE Estimator is the more reliable estimator.

Results: The results obtained with the PMGE estimator indicate that the $1 \%$ increase in economic growth increased carbon dioxide emission by $0.43 \%$.

Keywords: carbon dioxide emission; economic growth; environment; panel data analysis JEL: C33; O44; Q56

\section{Introduction}

In the last fifty years, economists have been discussing the reciprocity relationship between the environment and the economy on a market basis. Mainly, mainstream economic thinkers described these effects as market failures and defined them as "externalities", on the other hand, they put forward their resolutions in order to internalize externalities through economic interventions, including the market economy perspective. Economic discipline has been able to continue to solve these problems related to environment and market relations in various sub-branches with abstractions. Ecological economics has been a sub-discipline that brings a breath of fresh air to past studies and tries to create a new perspective by adding ethical values to the socio-economy. In addition, environmental taxes, which are taxing harmful social costs and are an environmental protection method, are considered as the most concrete recycling of solutions and interventions regarding the pricing of marginal social cost under the name of emissions taxes and the understanding that "punishment is a price". Thus, externalities were internalized, and these costs were priced to minimize marginal social costs. Although the economic policies used here attempt to reduce $\mathrm{CO} 2$ emissions with negative incentives, how successful environmental taxes are is controversial both at the country level and at the cross-country level.

The essence of environmental taxation, which is one of the measures taken to protect the environment in the long term, is essentially a negative incentive policy to reduce carbon emissions. On the other hand, besides the negative effects of carbon emissions on the environment, its relation with economic growth is one of the relations that economists think about in terms of the results of economic activity and try to make sense of in commodity creation as much as its ecological effect. In this study, the historical development of the study subfields, which includes the attention of economists to environmental impacts, 
will be given in a way to see the big picture, and then the direction and effect of the relationship between growth and individual energy emission will be explained with Member Countries of Organization of Islamic Cooperation (OIC).

\section{Literature review}

Environmental disaster and negative environmental exposure are the result of collective decisions of economic agents in the production sector (Dietz \& van der Straaten, 1992). Especially in the last decade, environmental awareness has emerged as a field of study both economically and politically (Spash, 1999). Although there is a wide range of literature researching the relationship between economic growth and carbon emissions, it can be easily seen that there are few studies dealing with this topic on base of Islamic Countries. All studies reviewed are given in table 1 in chronological order.

Considering the studies on table 1 , it can be clearly seen that almost all of the studies point out that there is a cointegration between economic growth and $\mathrm{CO} 2$ emissions and causality one-way or two-way from economic growth to $\mathrm{CO} 2$ emissions. Besides it, some studies found $\mathrm{N}$-type relationship while other one's observed U-type relationship. In addition to this, they show that the strongness of the relationship between the two variables varies according to the income group or country group. Unlike the studies below, this study examines the relationship in the context of Islamic countries, and in this respect, the study differs from previous studies.

Microeconomics and macroeconomics, the two main branches of economics, have basically built their methodologies on understanding the output effect of the decisions taken by economic actors. With the economic modeling method used frequently in economics and the assumptions established, it builds the economic relations of these actors, who are in search of stable equilibrium, by making decisions that will maximize their own preferences. On the other hand, the ecological economy is a sub-branch of economy, which includes the financial evaluation of positive environmental services and negative externalities, as well as physical assessments of the environmental impacts of the human economy measured by new indicators. This branch gives importance to social indicators in addition to monetary indicators. Studying the relationships between property rights and natural resource management is another key focus of the ecological economy. The ecological economy supports multi-criteria evaluations on cost-benefit analysis and emphasizes the immeasurability of values. That is, Ecological Economics without "traditional macroeconomic growth" has developed an ecological macroeconomics. On the other hand, in the literature, the most cited study examined the relationship between carbon dioxide emissions, which is a greenhouse gas at the center of global warming estimates, and economic development.

Accordingly, the estimates from global panel data suggested the concept of decreasing CO2 marginal emission tendency (MPE - marginal propensity 
to emit) to economic terminology and showed a decrease in the tendency to emit carbon dioxide as GDP per capita increases (Holtz-Eakin \& Selden, 1995). In their study, Holtz-Eakin \& Selden (1995) stated that the growth of global carbon dioxide emissions will continue with 1.8 percent per year for the foreseeable future and this rate is not a result that is not sensitive to average output growth. Again, in the study, it is predicted that the emission increase will continue especially in low-income countries. He emphasized on the results of distribution of emission reduction policies as the second factor, which is explained by the fact that it will grow fastest in low-income countries. It was also mentioned in the study that efforts to reduce emissions will have a negative impact on economic growth and impose a burden on low-income countries.

The question of whether carbon emissions diverge from economic growth is one of the main problems that come to mind for the link between environment and economic growth.

This relationship, which ecological economics also tries to measure, is taken as far as the fiction of economic growth to minimize environmental pollution. However, in the last study, Wang \& Jian (2020) have focused on the fact that the emission effect in emerging markets is very important in the global carbon emission and found that there is a strong relationship between their economic growth and emissions.

Wawrzyniak \& Doryń (2020), in their articles which includes the institutional economics perspective, analyzed effect of carbon dioxide dependent economic growth on the quality of institutions in the scope of 93 emerging and developing countries between 1995-2013. According to them, the effectiveness of governments can affect economic growth with $\mathrm{CO} 2$ emissions. In essence, the study has brought a new alternative perspective to the environmental Kuznet curve based on institutional quality. Since it reinterpreted this relationship, he offered a different perspective on the economic growth-emission link. The main purpose of the study was to investigate the effect of GDP per capita on carbon dioxide emissions depending on the quality of institutions. Academics examined the concept of marginal impact of GDP per capita in full and diminishing specialization, possible government effectiveness, government control situation scenarios, and showed effect on growth on its possible path (Wawrzyniak \& Doryń, 2020).

In this study, it is measured econometrically whether the effect of $\mathrm{CO} 2$ emission trend on economic growth, as stated in theory, is decreasing. On the other hand, since we do not include intervention and economic institutions from an institutional point of view, it essentially causes our study to be examined under ecological economics.

\section{Methods}

The table 2 contains abbreviations and explanations regarding the variables used in the analysis. The study uses data from 50 countries that are members 
of the Organization of Islamic Cooperation (OIC). The countries in the scope of the study are given in the table 3 .

As of today, Organization of Islamic Cooperation has 57 members. At this point, the availability of data was decisive in the selection of the country in the study. In the study, the model created by Gülmez (2015) was followed in determining the effects of economic growth of countries on carbon dioxide emissions.

\subsection{Model, data set and countries}

This model can be formulated as follows:

$$
L C O_{i t}=\beta_{0}+\beta_{1} L G D P C_{i t}+u_{i t} .
$$

In the model $L C O_{i t}$ shows the natural logarithm of Carbon Dioxide Emissions Per Capita for each country. Again, $L_{G D P C}$ shows the GDP per capita for the countries. The inclusion of this variable in the model was realized by taking its natural logarithm. $u_{i t}$ is the error term of the model. The model is arranged in full logarithmic form. Therefore, the coefficients directly express the flexibility. On the other hand, the coefficient of the variable $L G D P C_{i t}$ is expected to be positive, based on both early academic studies and theoretical expectations.

Summary statistics on the variables used in the analysis in the table 4 are included. When the statistics are analyzed, it is seen that as a result of taking the natural logarithms of the variables, the size of their ranges have approached each other. The average value of the LCO series is greater than its median. The slope coefficient is -0.04 . These two values show that this series is skewed to the left. But the opposite is true for the LGPC series. The average value of this series is less than the median value. Therefore, the series is skewed to the right. The kurtosis value of both series is less than the normal distribution kurtosis value. This means the two series are more flattened than the normal distribution. In addition, Jarque-Bera test statistics are larger than 5.99, indicating that the series do not have a normal distribution. Finally, the number of observations studied is 1150 .

\subsection{PMGE and MGE method}

In this study, the Pooled Mean Group Estimator (PMGE) and Mean Group Estimator (MGE) methods were used to analyze the economic growth and carbon dioxide emission amounts of the countries. These methods, unlike the methods that only provide long-term coefficient estimates, also enable the estimation of short-term coefficients by creating an error correction model.

Developed by Pesaran \& Smith (1995), MGE is created using the Autoregressive Distributed Lag Model (ARDL) models for each cross-section. Here, ARDL models are estimated first and then long-term parameters are obtained by taking the average of the long-term parameters obtained from these models. 
Thus, long-term parameters are allowed to change from unit to unit. PMGE estimator developed by Pesaran et al. (1999) is a mixture of Fixed Effects estimator and MGE estimator. At this point, the MGE estimator allows constant and slope parameters to change across units, while the constant effects estimator meant to allow constant coefficients to change across units but stipulates the condition of slope parameters to be fixed. PMGE estimator consisting of the combination of these two estimators; it keeps long-term parameters constant, allowing error variances and short-term parameters to change between units.

PMGE is based on the Auto Regressive Distributed Lag (ARDL) model with heterogeneous short-term dynamics. In this context, the unrestricted error correction model can be formulated as follows (Tatoğlu, 2013, p. 245):

$$
\Delta y_{i t}=\varphi \varepsilon_{i t-1}+\beta_{i}^{\prime} x_{i t}+\sum_{J=1}^{p-1} \Delta y_{i t-j}+\sum_{J=0}^{q-1} \partial_{i j} \Delta x_{i t-j}+\varepsilon_{i t} .
$$

where: $\varphi_{i}=-\left(1-\sum_{J=1}^{p} \lambda_{i j}\right), \beta_{i}=\sum_{J=0}^{q} \partial_{i j}, \lambda_{i j}^{*}=-\sum_{m=J+1}^{p} \lambda_{i m}, \partial_{i j}^{*}=-\sum_{m=J+1}^{q} \partial_{i m}$.

\section{Results}

In this section, the relationship between economic growth and carbon dioxide emissions will be tackled with the help of panel data analysis within the scope of the relevant countries. For this purpose, firstly, the cross-section dependencies of the variables used in the model will be determined, and then unit root tests related to the relevant variables will be conducted depending on the results of the horizontal cross-section dependence. Then, co-integration analysis will be conducted following determination of the stationarity levels of the variables and the results will be interpreted. Afterwards, causality analyzes will be performed and coefficients will be interpreted by obtaining coefficients for both all countries and individuals ones through PMGE and MGE estimators.

\subsection{Cross sectional dependency test}

Pesaran (2004, pp. 5-6) in his study derived a homogeneity test that can be used in cases where $\mathrm{N}>\mathrm{T}$. This test at the same time has a zero mean in cases where $\mathrm{N}$ and $\mathrm{T}$ are constant. This test can be used in a wide range of panel data analyzes that are exposed to multiple slope coefficients and error variances.

The table 5 shows the cross-section dependency test results for this test. When Pesaran (2004) CD test results are examined, probability values for each variable are statistically significant at the level of $1 \%$. This means that the $\mathrm{H}_{0}$ hypothesis that the series does not have a cross-section dependency is rejected and it is accepted that there is the cross-sectional dependency. These test results are to provide information about which unit root tests should be applied.

In panel data studies, unit root tests are divided into two as the first generation and the second generation. First generation tests are based on the as- 
sumption that there is no correlation between units, and if there is a correlation between units, the power of these tests weakens. Examples of first-generation tests are Breitung (2000), Choi (2001), Hadri (2000), Harris \& Tzavalis (1999), Im et al. (2003), Levin et al.(2002) and Maddala \& Wu (1999) tests. For the second-generation tests, Bai \& Ng (2004), Moon \& Perron (2004), O'Connell (1998), Pesaran (2004; 2007) tests can be given (Tatoğlu, 2013, p. 199). For this reason, Pesaran (2007) CIPS unit root test will be used, which considers cross-sectional dependency.

\subsection{Unit root test results}

In the panel data analysis, it is important to examine the stationarity levels of the series in order to perform long-run cointegration analyze. In this context, Pesaran (2007) developed the Cross-Sectionally Augmented IPS test by averaging the Horizontal Cross-Sectional Dickey Fuller (CADF) statistics. The table 6 contains the CIPS unit root test results for the variables used in the analysis.

In model with both constant and trend, which can also be seen from the table 6, CIPS test statistics for the LCO series are higher than $5 \%$ critical table value for the LCO series. Again, in models with both constant and trend, the CIPS test statistics are higher than 5\% critical table value for the level values of LGDPC series. This indicates that the series are not stationary with their level values. However, when the differences of the series are taken, this situation changes and CIPS test statistics take values below all $5 \%$ critical table values in both models. This means that both series become stationary when their first differences are taken. Co-integration analysis can be performed for the series with the same level of stationarity.

\subsection{Cointegration analysis results}

Following with the determination that the series are I(l), a cointegration analysis can be performed in order to determine whether they move jointly in the long term. The table 7 contains the results of Pedroni $(1999 ; 2004)$ and Westerlund (2007) cointegration tests for the relevant variables.

As can be seen from the table 7, probability values are lower than $5 \%$ in all Westerlund cointegration tests and 6 of Pedroni cointegration tests. This indicates that in both tests, the $\mathrm{H}_{0}$ hypothesis that there is no cointegration between the series is rejected and it is concluded that the series are cointegrated in the long run.

\subsection{Causality analysis results}

After determining that the series are cointegrated, the relationship between countries' growth rates and carbon dioxide emissions in the relevant period were examined with the help of Granger Causality and Dumitrescu \& Hurlin (2012) causality analyzes. The causality analysis results are given in table 8 . 
According to the causality analysis results, the probability values for both tests are statistically significant at the level of $5 \%$. This means that there is a two-way causality between economic growth and carbon dioxide emissions of countries.

\subsection{PMGE and MGE results}

The table 9 shows the PMGE and MGE analysis results showing the general short and long run coefficients for the model used in the study. As can be seen from the estimation results, all of the coefficients obtained from PMGE and MGE analyzes are statistically significant at $1 \%$ level. As a result of both analyzes, the coefficients of ec, which is the error correction term, are negative and statistically significant. These findings point out that there is a long-term relationship between economic growth and carbon dioxide variables between 1995 and 2017 within the scope of the countries included in both models. According to the PMGE model, a deviation between the two variables will come to equilibrium after approximately three and a half periods $(1 / 0.2764647=3.617)$. For the MGE model, this period is approximately 2.5 periods. On the other hand, the coefficient of the LGDPC variable for the PMGE model was 0.66 for the long term and 0.44 for the short term. When it comes to the MGE model, $1 \%$ increase in economic growth increases the carbon dioxide emission $0.89 \%$ in the long term and $0.33 \%$ in the short term.

At this point in the literature, Hausman Test is conducted regarding which model results are more reliable. The table 10 shows the results of the Hausman test. As can be seen from the table 10, the probability value of Hausman Test statistics was calculated as 0.33 . This value indicates that null hypothesis cannot be rejected at 5\% statistical significance level. Therefore, it is concluded that there is no systematic difference between the coefficients and the MGE estimator is a more valid and reliable estimator. However, in order to be compared, the results related to the MGE estimator will be given in the tables 9 and 11.

The table 11 shows the long-term and short-term coefficient estimates for each country calculated with the PMGE and MGE estimators and obtained for the model of the study. As can be seen from the table 11, the PMGE estimator provides a single coefficient estimate for all countries in the long run, while the MGE estimator gives individual results for each country, both in the long run and in the short run. The estimated long-term coefficient for the economic growth variable with the PMGE estimator was found to be 0.6608871 , and this value is the same as the model estimated above. According to this result, $1 \%$ increase in the economic growth variable in the long-term increases carbon dioxide emission by $0.66 \%$. When error correction parameters are evaluated within the scope of related countries, error correction parameter is negative in all 50 countries. However, the error correction parameter of 27 countries is statistically significant at the level of $5 \%$. In countries where error correction parameter is statistically significant; when these parameters are analyzed in terms 
of magnitudes, three countries with the highest values found were Ivory Coast (0.67), Togo (0.65) and Kuwait (0.61) respectively. For Turkey, this parameter was estimated to be 0.34 . it means that in case a deviation that may occur between the two variables, this relation will come again to equilibrium in about three periods for Turkey $(1 / 0.34=2.9411)$. According to the results of the forecast, such a deviation will correct in the Ivory Coast, Togo and Kuwait in about 1.5 periods.

On the other hand, considering the statistical significance of the coefficients, the coefficients of Bahrain (2.40), Albania (1.82), Niger (1.61), Ivory Coast (1.45), Indonesia (1.41), Egypt (1.35) Pakistan (1.05), Tunisia (0.71), Gabon (0.63) and Turkey (0.41) are statistically significant at the $5 \%$ level. If situations of the countries are assessed $\neg$ in terms of magnitudes of coefficients, as can be seen above, among the countries whose coefficients are statically significant, Bahrain has the highest coefficient while the lowest coefficient belongs to Turkey. Coefficients estimates point out that $1 \%$ increase in economic growth during the period studied in the relevant countries increases in carbon dioxide emissions by $2.40 \%$ in Bahrain and $0.41 \%$ in Turkey. This case, in the sense that the production increases converted to less carbon dioxide for countries in scope, can be interpreted as a positive sign for Turkey.

\section{Conclusion}

In the last two centuries, the economic growth efforts and industrialization activities of the countries have caused the pollution of the environment and the air even if it has increased the welfare of the humanity. Thus, this issue has become a focus of interest for the governments and academicians of many countries in terms of investigating the effects of these increases in the production of goods and services on the environment. In this study, the relationship between economic growth and carbon dioxide emissions of the countries within the scope of 50 countries that are members of the Organization of Islamic Cooperation was examined with this motivation. The data set of the study covers the annual data between 1995 and 2017, and the coefficients of this relationship are estimated by PMGE and MGE estimators.

During the analysis, firstly, cross-sectional dependency tests related to the variables used in the model were performed. According to Pesaran (2004) test results, it was concluded that there is a cross-sectional dependency between the series within the period examined. Following this determination, Pesaran (2007) CIPS unit root tests, one of the second-generation unit root tests, were applied to find out the stationarity levels of the series and it was concluded that both series were I(l). Afterwards, the cointegration relationship between the series was determined by Pedroni (1994) and Westerlund (2007) tests. Then, with the help of Granger Causality and Dumitrescu \& Hurlin (2012) causality analysis, the causality direction and presence among the variables were investigated. The results of the analysis indicate that two-way causality exists between eco- 
nomic growth and the carbon dioxide variable within the country group under consideration and within the period studied.

In the end of the analysis section, the coefficients regarding the direction and size of the relationship between the two variables were estimated through PMGE and MGE methods. The Hausman Homogeneity test, which of these methods produces more valid results, shows that the long-term parameters of PMGE estimators satisfy homogeneity conditions.

In the parameter estimates obtained with PMGE method, error correction parameters were negative and significant for generally all countries. This result indicates the existence of a relationship in balance in the long term if there is a deviation between the variables in the short term. According to PMG results, the long-term coefficient of the economic growth variable was found to be 0.66 for all countries and this coefficient is statistically significant at the level of $5 \%$. This coefficient indicates that the $1 \%$ increase in economic growth during the period examined increased the countries' carbon dioxide emissions by an average of $0.66 \%$. On the other hand, when the short-term parameter estimates for the countries are examined, the coefficients of Bahrain (2.40), Albania (1.82), Niger (1.61), Ivory Coast (1.45), Indonesia (1.41), Egypt (1.35), Pakistan (1.05), Tunisia (0.71), Gabon (0.63) and Turkey (0.41) were statistically significant at the $5 \%$ level.

When sorted in the order of magnitude of the coefficients, among the countries who's their coefficients are statistically significant, Bahrain has the highest coefficient, and the lowest coefficient belongs to Turkey. A 1\% increase in economic growth that occurred during the period examined in the countries concerned by this coefficient increases carbon dioxide emissions 2.40\% in Bahrain and $0.41 \%$ in Turkey. These findings can be interpreted as a positive sign for Turkey compared to countries in scope in terms of transformation of production to less carbon dioxide.

\section{References}

Alam, M.M., Murad, M.W., Noman, A.H.M., \& Ozturk, I. (2016). Relationships among carbon emissions, economic growth, energy consumption and population growth: testing Environmental Kuznets Curve hypothesis for Brazil, China, India and Indonesia. Ecological Indicators, 70, 466-479. https://doi.org/10.1016/j.ecolind.2016.06.043.

Albayrak, E. N., \& Gökçe, A. (2015). Ekonomik büyüme ve çevresel kirlilik ilişkisi: cevresel Kuznets eğrisi ve Türkiye örneğ. Sosyal Bilimler Araştırma Dergisi, 4(2), 279-301.

Alper, F.Ö., \& Alper, A.E. (2017). Karbondioksit emisyonu, ekonomik büyüme, enerji tüketimi ilişkisi: Türkiye için bir ARDL sınır testi yaklaşımı. Sosyoekonomi, 25(33), 145-156. https://doi.org/10.17233/sosyoekonomi.292114. 
Aşıcı, A.A. (2013). Economic growth and its impact on environment: a panel data analysis. Ecological indicators, 24, 324-333. https://doi.org/10.1016/j. ecolind.2012.06.019.

Atgür, M. (2021). Ekonomik büyüme, enerji tüketimi ve karbon emisyonları ilişkisi: Çin örneği. Afyon Kocatepe Üniversitesi Sosyal Bilimler Dergisi, 23(1), 172-186. https://doi.org/10.32709/akusosbil.696857.

Ayşe, A.R.I., \& Zeren, F. (2011). CO2 emisyonu ve ekonomik büyüme: panel veri analizi. Yönetim ve Ekonomi Dergisi, 18(2), 37-47.

Aytun, C. (2014). Çevresel Kuznets eğrisi hipotezi: panel veri analizi. Akademik Bakış Uluslararası Hakemli Sosyal Bilimler Dergisi, (44).

Bai, J., Ng, S. (2004). A panic attack on unit roots and cointegration. Econometrica, 72(4), 1127-1177. https://doi.org/10.1111/j.1468-0262.2004.00528.x.

Bekar, S.A. (2018). The relationship between Co2 emission and economic growth in Turkey: 1977-2011. Uluslararasi İktisadi ve İdari İncelemeler Dergisi, 193-206. https://doi.org/10.18092/ulikidince.428059.

Boopen, S., \& Vinesh, S. (2011). On the relationship between CO2 emissions and economic growth: the Mauritian experience. Retrieved 14.08.2021 from http://www.csae.ox.ac.uk/conferences/2011-EDiA/papers/776-Seetanah. pdf.

Breitung, J. (2001). The local power of some unit root tests for panel data. Advances in Econometrics, 15 (2), 161-177. https://doi.org/10.1016/ S0731-9053(00)15006-6.

Burnett, J.W., Bergstrom, J.C., \& Wetzstein, M.E. (2013). Carbon dioxide emissions and economic growth in the US. Journal of Policy Modeling, 35(6), 1014-1028. https://doi.org/10.1016/j.jpolmod.2013.08.001.

Çetin, M., \& Seker, F. (2014). Ekonomik büyüme ve dış ticaretin çevre kirliliği üzerindeki etkisi: Türkiye için bir ARDL sınır testi yaklaşımı. Yönetim ve Ekonomi Dergisi, 21(2), 213-230. https://doi.org/10.18657/yecbu.48366.

Chaabouni, S., Zghidi, N., \& Mbarek, M.B. (2016). On the causal dynamics between CO2 emissions, health expenditures and economic growth. Sustainable Cities and Society, 22, 184-191. https://doi.org/10.1016/j.scs.2016.02.001.

Choi, I. (2001). Unit root tests for panel data. Journal of International Money and Finance, 20(2), 249-272. https://doi.org/10.1016/S0261-5606(00)00048-6.

Dal, M.M., Karakaya, E., \& Bulut, Ş. (2013). Çevresel Kuznets eğrisi ve Türkiye: ampirik bir analiz. Dumlupinar Üniversitesi Sosyal Bilimler Dergisi, 85-96.

Dietz, F.J., \& van der Straaten, J. (1992). Rethinking environmental economics : missing links between economic theory and environmental policy. Journal of Economic Issues, 26(1), 27-51. https://doi.org/10.1080/00213624.199 2.11505261 .

Dumitrescu, E.-I., \& Hurlin, C. (2012). Testing for Granger noncausality in heterogeneous panels. Economic Modelling, 29(4), 1450-1460. https:// doi.org/10.1016/j.econmod.2012.02.014. 
Ghorashi, N., \& Alavi Rad, A. (2017). CO2 emissions, health expenditures and economic growth in Iran: apply dynamic simultaneous-equations models. Journal of Community Health Research, 6(2), 109-116.

Gülmez, A. (2015). OECD ülkelerinde ekonomik büyüme ve hava kirliliği ilişkisi: panel veri analizi. Kastamonu Üniversitesi İktisadi ve İdari Bilimler Fakültesi Dergisi, 9(3), 18-30.

Gündüz, H. (2014). Çevre kirliliği ile gelir arasındaki ilişkinin incelenmesi: panel eşbütünleşme analizi ve hata düzeltme modeli. Marmara Üniversitesi İktisadi ve İdari Bilimler Dergisi, 36(1), 409-423.

Hadri, K. (2000). Testing for stationarity in heterogeneous panel data. The Econometrics Journal, 3(2), 148-16. https://doi.org/10.1111/1368-423X.00043.

Harris, R.D., \& Tzavalis, E. (1999). Inference for unit roots in dynamic panels where the time dimension is fixed. Journal of Econometrics, 91(2), 201-226. https://doi.org/10.1016/S0304-4076(98)00076-1.

Holtz-Eakin, D., \& Selden, T.M. (1995). Stoking the fires: CO2 emissions and economic growth. Journal of Public Economics, 57(1), 85-101. https://doi. org/10.1016/0047-2727(94)01449-X.

Im, K.-S.O., Pesaran, M.H., \& Shin, Y. (2003). Testing for unit roots in heterogeneous panels. Journal of Econometrics, 115(1), 53-74. https://doi. org/10.1016/S0304-4076(03)00092-7.

Konat, G. (2021). Türkiye'de karbondioksit emisyonu ve ekonomik büyüme ilişkisi: yapısal kırılmalı testlerden kanıtlar. Siyaset, Ekonomi ve Yönetim Araştırmaları Dergisi, 9(1), 105-122.

Levin, A., Lin, C.-F., \& Chu, C.-S.J. (2002). Unit root tests in panel data: asymptotic and finite-sample properties. Journal of Econometrics, 108(1), 1-24. https://doi.org/10.1016/S0304-4076(01)00098-7.

Maddala, G.S., \& Wu, S. (1999). A comparative study of unit root tests with panel data and a new simple test. Oxford Bulletin of Economics and Statistics, 61(S1), 631-652. https://doi.org/10.1111/1468-0084.0610s1631.

Moon, H.R., \& Perron, B. (2004). Testing for a unit root in panels with dynamic factors. Journal of Econometrics, 122(1), 81-126.

O'Connell, P.G.J. (1998). The overvaluation of purchasing power parity. Journal of International Economics, 44(1), 1-19. https://doi.org/10.1016/ S0022-1996(97)00017-2.

Pata, U.K. \& Terzi, H. (2016). The relationship between aggregated-disaggregated energy consumption and economic growth in Turkey. Business and Economics Research Journal, 7(4), 1-15. https://doi.org/10.20409/ berj. 2016422335.

Pata, U.K. (2018a). Renewable energy consumption, urbanization, financial development, income and $\mathrm{CO} 2$ emissions in Turkey: testing EKC hypothesis with structural breaks. Journal of Clenaer Production, 187, 770-749. 
Pata, U.K. (2018b). The effect of urbanization and industrialization on carbon emissions in turkey: evidence from ARDL bounds testing procedure. Environmental Science and Pollution Research, 25, 7740-7747. https://doi. org/10.1007/sl1356-017-1088-6.

Pedroni, P. (1999). Critical values for cointegration tests in heterogeneous panels with multiple regressors. Oxford Bulletin of Economics and Statistics, 61(S1), 653-670. https://doi.org/10.1111/1468-0084.0610s1653.

Pedroni, P. (2004). Panel cointegration: asymptotic and finite sample properties of pooled time series tests with an application to the PPP hypothesis. Econometric Theory, 20(3), 597-625. https://doi.org/10.1017/ S0266466604203073.

Pesaran, M.H. (2004). General diagnostic tests for cross section dependence in panels. Cambridge Working Papers in Economics, 0435, 1-41.

Pesaran, M.H. (2007). A simple panel unit root test in the presence of cross section dependence. Journal of Applied Econometrics, 22(2), 265-312. https:// doi.org/10.1002/jae.951.

Pesaran, M.H., \& Smith, R. (1995). Estimating long-run relationships from dynamic heterogeneous panels. Journal of Econometrics, 68(1), 79-113. https:// doi.org/10.1016/0304-4076(94)01644-F.

Pesaran, M.H., Shin, Y., \& Smith, R.P. (1999). Pooled Mean Group Estimation of Dynamic Heterogeneous Panels. Journal of the American Statistical Association, 94(446), 621-634. https://doi.org/10.2307/2670182.

Raza, S.A., \& Shah, N. (2018). Testing environmental Kuznets curve hypothesis in G7 countries: the role of renewable energy consumption and trade. Environmental Science and Pollution Research, 25(27), 26965-26977. https:// doi.org/10.1007/s11356-018-2673-z.

Ritchie, H., \& Roser, M. (2020). $\mathrm{CO}_{2}$ and greenhouse gas emissions. Retrieved 18.08.2021 from https://ourworldindata.org/ co2-and-other-greenhouse-gas-emissions.

Roca, J., Padilla, E., Farré, M., \& Galletto, V. (2001). Economic growth and atmospheric pollution in Spain: discussing the environmental Kuznets curve hypothesis. Ecological Economics, 39(1), 85-99. https://doi.org/10.1016/ S0921-8009(01)00195-1.

Saatçi, M., \& Dumrul, Y. (2011). Çevre kirliliği ve ekonomik büyüme ilişkisi: çevresel kuznets eğrisinin Türk ekonomisi için yapisal kirilmali eş-bütünleşme yöntemiyle tahmini. Erciyes Üniversitesi İktisadi ve İdari Bilimler Fakültesi Dergisi, (37), 65-86.

Şahinöz, A., \& Fotourehchi, Z. (2013). Çevresel kuznets eğrisi: ındirgenmiş ve ayriştirilmiş modellerle ampirik bir analiz. Hacettepe Üniversitesi İktisadi ve İdari Bilimler Fakültesi Dergisi, 31(1), 199-224.

Sancar, C., \& Polat, M.A. (). CO2 emisyonları, ekonomik büyüme ve sağlık harcamaları ilişkisi: Türkiye ve seçilmiş ülke örnekleri için ampirik bir uygulama. MANAS Sosyal Araștırmalar Dergisi, 10(1), 236-252. https://doi. org/10.33206/mjss.748253. 
Sarisoy, S., \& Yildiz, F. (2013). Karbondioksit (CO2) emisyonu ve ekonomik büyüme ilişkisi: gelişmiş ve gelişmekte olan ülkeler için panel veri analizi. Sosyal Bilimler Metinleri, (1), 1-19.

Spash, C.L. (1999). The development of environmental thinking in economics. Environmental Values, 8(4), 413-435. http://dx.doi. org/10.3197/096327199129341897.

Tatoğlu, F.Y. (2013). İleri panel veri analizi. Beta Yayınları.

Topalli, N. (2016). CO2 emisyonu ve ekonomik büyüme arasındaki ilişki: Hindistan, Çin, Brezilya ve Güney Afrika için panel veri analizi. Çankır Karatekin Üniversitesi İktisadi ve İdari Bilimler Fakültesi Dergisi, 6(1), 427-447.

Uysal, D., Yapraklı, H. (2016). Kişi başına düşen gelir, enerji tüketimi ve karbondioksit (Co2) emisyonu arasındaki ilişkinin yapısal kırılmalar altında analizi: Türkiye örneği. Sosyal Ekonomik Araştırmalar Dergisi, 16(31), 186202. https://doi.org/10.30976/susead.302164.

Wang, Q., \& Jiang, R. (2020). Is carbon emission growth decoupled from economic growth in emerging countries: new insights from labor and investment effects. Journal of Cleaner Production, 248, 119188. https://doi.org/10.1016/j. jclepro.2019.119188.

Wawrzyniak, D., \& Doryń, W. (2020). Does the quality of institutions modify the economic growth-carbon dioxide emissions nexus: evidence from a group of emerging and developing countries. Economic Research: Ekonomska Istrazivanja, 33(1), 124-144. https://doi.org/10.1080/13316 77X.2019.1708770.

Westerlund, J. (2007). Testing for error correction in panel data. Oxford Bulletin of Economics and Statistics, 69(6), 709-748. https://doi. org/10.1111/j.1468-0084.2007.00477.x.

World Bank. (2021). World development indicators. Retrieved 18.08.2021 from https://databank.worldbank.org/home.aspx.

\section{Acknowledgements}

Author contributions: authors have given an approval to the final version of the article. Authors contributed to this work as follows: M.V.K. developed the concept and designed the study, S.S.Y. collected the data and analysed and interpreted the data, M.G.Ö. prepared the draft of the article, M.G.Ö. revised the article critically for important intellectual content.

Funding: this research was fully funded by the BC GRUP AS, Turkey. 


\section{Appendix}

Table 1.

\section{Literature review}

\begin{tabular}{|c|c|c|c|c|}
\hline Authors & Range/date & Sample size/country & Method & Results \\
\hline $\begin{array}{l}\text { Sancar \& } \\
\text { Polat }(2021)\end{array}$ & $\begin{array}{l}\text { 2000-2016 } \\
\text { annually }\end{array}$ & $\begin{array}{l}\text { Turkey, Brazil, } \\
\text { Mexico, China, } \\
\text { India and South } \\
\text { Africa }\end{array}$ & $\begin{array}{l}\text { Dumitrescu-Hurlin } \\
\text { Causality Test }\end{array}$ & $\begin{array}{l}\text { There is a two-way causality rela- } \\
\text { tionship between economic growth } \\
\text { and CO2 emissions. }\end{array}$ \\
\hline $\begin{array}{l}\text { Konat } \\
(2021)\end{array}$ & $\begin{array}{l}\text { 1960-2016 } \\
\text { annually }\end{array}$ & Turkey & $\begin{array}{l}\text { Dynamic Ordinary } \\
\text { Least Squares } \\
\text { (DOLS) } \\
\end{array}$ & $\begin{array}{l}\text { There is a long-term cointegration } \\
\text { between economic growth and CO2 } \\
\text { Emissions. }\end{array}$ \\
\hline $\begin{array}{l}\text { Atgür } \\
(2021)\end{array}$ & $\begin{array}{l}\text { 1971-2014 } \\
\text { annually }\end{array}$ & China & $\begin{array}{l}\text { Johansen Cointegra- } \\
\text { tion, Vector Error } \\
\text { Correction Model } \\
\text { (VECM) }\end{array}$ & $\begin{array}{l}\text { There is a long-term and significant } \\
\text { relationship between economic } \\
\text { growth and energy consumption } \\
\text { and carbon emissions in China. } \\
\text { Economic growth and energy use } \\
\text { positively affect carbon emissions. }\end{array}$ \\
\hline $\begin{array}{l}\text { Wang \& } \\
\text { Jiang }(2020)\end{array}$ & $\begin{array}{l}\text { 2000-2014 } \\
\text { annually }\end{array}$ & China & $\begin{array}{l}\text { Logarithmic Mean } \\
\text { Divisia Index }\end{array}$ & $\begin{array}{l}\text { China's CO2 emissions increased } \\
\text { with rapid economic growth. }\end{array}$ \\
\hline $\begin{array}{l}\text { Raza \& Shah } \\
(2018)\end{array}$ & $\begin{array}{l}\text { 1991-2016 } \\
\text { annually }\end{array}$ & G7 countries & $\begin{array}{l}\text { Fully Modified Least } \\
\text { Squares (FMOLS), } \\
\text { DOLS, Panel } \\
\text { Causality }\end{array}$ & $\begin{array}{l}\text { Economic growth increases the CO2 } \\
\text { emission. }\end{array}$ \\
\hline $\begin{array}{l}\text { Bekar } \\
(2018)\end{array}$ & $\begin{array}{l}\text { 1977-2014 } \\
\text { annually }\end{array}$ & Turkey & $\begin{array}{l}\text { Toda-Yamamoto } \\
\text { and Dolado-Lütke- } \\
\text { pohl VAR Causality }\end{array}$ & $\begin{array}{l}\text { There is a one-way and positive } \\
\text { causality relationship from CO } 2 \text { emis- } \\
\text { sions to economic growth in Turkey. }\end{array}$ \\
\hline Pata (2018b) & $\begin{array}{l}\text { 1974-2013 } \\
\text { annually }\end{array}$ & Turkey & $\begin{array}{l}\text { ARDL (Autoregres- } \\
\text { sive Distributed Lag) }\end{array}$ & $\begin{array}{l}\text { There is a long-run relationship } \\
\text { between GDP and CO2 emissions. }\end{array}$ \\
\hline Pata (2018a) & $\begin{array}{l}\text { 1974-2014 } \\
\text { annually }\end{array}$ & Turkey & ARDL Bounds Test & $\begin{array}{l}\text { As GDP increases in Turkey, per } \\
\text { capita CO } 2 \text { emissions continue } \\
\text { to increase. }\end{array}$ \\
\hline $\begin{array}{l}\text { Alper \& } \\
\text { Alper (2017) }\end{array}$ & $\begin{array}{l}\text { 1985-2014 } \\
\text { annually }\end{array}$ & Turkey & ARDL Bounds Test & $\begin{array}{l}\text { Economic growth and energy } \\
\text { consumption caused environmental } \\
\text { pollution to increase. }\end{array}$ \\
\hline $\begin{array}{l}\text { Ghorashi \& } \\
\text { Rad (2017) }\end{array}$ & $\begin{array}{l}\text { 1972-2012 } \\
\text { annually }\end{array}$ & Iran & GMM & $\begin{array}{l}\text { The positive bidirectional causality } \\
\text { relationship between CO2 emissions } \\
\text { and economic growth. }\end{array}$ \\
\hline $\begin{array}{l}\text { Alam et al. } \\
(2016)\end{array}$ & $\begin{array}{l}\text { 1970-2012 } \\
\text { annually }\end{array}$ & $\begin{array}{l}\text { India, Indonesia } \\
\text { China, Brazil }\end{array}$ & $\begin{array}{l}\text { Autoregressive Dis- } \\
\text { tributed Lag Bound } \\
\text { Test }\end{array}$ & $\begin{array}{l}\text { For all four countries, CO2 emis- } \\
\text { sions have increased statistically } \\
\text { significantly with increases in energy } \\
\text { and consumption income. }\end{array}$ \\
\hline $\begin{array}{l}\text { Topalli } \\
\text { (2016) }\end{array}$ & $\begin{array}{l}\text { 1980-2010 } \\
\text { annually }\end{array}$ & $\begin{array}{l}\text { India, China, Brazil, } \\
\text { South Africa }\end{array}$ & VECM & $\begin{array}{l}\text { The increase of GDP by } 1 \% \text { raises } \\
\mathrm{CO} 2 \text { emission almost by } 0.55 \% \\
\text { in related countries. }\end{array}$ \\
\hline $\begin{array}{l}\text { Chaabouni } \\
\text { et al. (2016) }\end{array}$ & $\begin{array}{l}\text { 1995-2013 } \\
\text { annually }\end{array}$ & 51 countries & $\begin{array}{l}\text { Generalized Method } \\
\text { of Moments (GMM) }\end{array}$ & $\begin{array}{l}\text { For } 51 \text { Countries, there is a two-way } \\
\text { causality between GDP and CO2 } \\
\text { emissions. }\end{array}$ \\
\hline $\begin{array}{l}\text { Pata \& Terzi } \\
(2016)\end{array}$ & $\begin{array}{l}\text { 1972-2011 } \\
\text { annually }\end{array}$ & Turkey & $\begin{array}{l}\text { Dolado-Lütkepohl } \\
\text { (DL) VAR Granger } \\
\text { Causality }\end{array}$ & $\begin{array}{l}\text { Economic growth increases CO2 } \\
\text { emissions. }\end{array}$ \\
\hline $\begin{array}{l}\text { Uysal \& } \\
\text { Yapraklı } \\
(2016)\end{array}$ & $\begin{array}{l}\text { 1968-2011 } \\
\text { annually }\end{array}$ & Turkey & $\begin{array}{l}\text { Hatemi-J Cointegra- } \\
\text { tion Test }\end{array}$ & $\begin{array}{l}\text { There is a cointegration between GDP } \\
\text { Per Capita and CO } 2 \text { emissions. }\end{array}$ \\
\hline
\end{tabular}




\begin{tabular}{|c|c|c|c|c|}
\hline Authors & Range/date & Sample size/country & Method & Results \\
\hline $\begin{array}{l}\text { Albayrak } \\
\text { \& Gökçe } \\
(2015)\end{array}$ & $\begin{array}{l}\text { 1975-2010 } \\
\text { annually }\end{array}$ & Turkey & $\begin{array}{l}\text { Johansen Cointegra- } \\
\text { tion, VECM }\end{array}$ & $\begin{array}{l}\text { As the income level increases, envi- } \\
\text { ronmental pollution and destruction } \\
\text { increase initially, and after higher } \\
\text { income levels, environmental im- } \\
\text { provement begins. }\end{array}$ \\
\hline $\begin{array}{l}\text { Gülmez } \\
\text { (2015) }\end{array}$ & $\begin{array}{l}\text { 2000-2012 } \\
\text { annually }\end{array}$ & 24 OECD countries & $\begin{array}{l}\text { DOLS, Panel Grang- } \\
\text { er Causality }\end{array}$ & $\begin{array}{l}\text { There is a cointegration relation- } \\
\text { ship between economic growth } \\
\text { and air CO2 Emissions in the long } \\
\text { run and unidirectional causality from } \\
\text { economic growth to CO2 Emissions. }\end{array}$ \\
\hline $\begin{array}{l}\text { Gündüz } \\
\text { (2014) }\end{array}$ & $1960-2018$ & 18 OECD countries & $\begin{array}{l}\text { Pooled Mean Group } \\
\text { Estimator (PMGE) }\end{array}$ & $\begin{array}{l}\text { There is a cointegration relationship } \\
\text { between environmental pollution } \\
\text { and economic growth. }\end{array}$ \\
\hline $\begin{array}{l}\text { Aytun } \\
(2014)\end{array}$ & $\begin{array}{l}\text { 1981-2001 } \\
\text { annually }\end{array}$ & 83 countries & FMOLS & $\begin{array}{l}\text { Economic growth caused carbon } \\
\text { emissions to increase. }\end{array}$ \\
\hline $\begin{array}{l}\text { Saatçi \& } \\
\text { Dumrul } \\
(2011)\end{array}$ & $\begin{array}{l}\text { 1950-2007 } \\
\text { annually }\end{array}$ & Turkey & $\begin{array}{l}\text { Kejriwal Cointegra- } \\
\text { tion Test }\end{array}$ & $\begin{array}{l}\text { There is a long run relationship } \\
\text { between economic pollution and eco- } \\
\text { nomic growth. }\end{array}$ \\
\hline $\begin{array}{l}\text { Çetin \& } \\
\text { Seker (2014) }\end{array}$ & $\begin{array}{l}\text { 1980-2010 } \\
\text { annually }\end{array}$ & Turkey & ARDL Bound Test & $\begin{array}{l}\text { There is a long run relationship } \\
\text { between economic growth and } \mathrm{CO} 2 \\
\text { Emissions. }\end{array}$ \\
\hline $\begin{array}{l}\text { Burnett et } \\
\text { al. (2013) }\end{array}$ & $\begin{array}{l}\text { 1981-2003 } \\
\text { monthly }\end{array}$ & US & DOLS & $\begin{array}{l}\text { Economic growth makes emissions } \\
\text { intensities to drive. }\end{array}$ \\
\hline $\begin{array}{l}\text { Şahinöz \& } \\
\text { Fotourehchi } \\
(2013)\end{array}$ & $\begin{array}{l}\text { 1994-2010 } \\
\text { annually }\end{array}$ & 26 OECD countries & $\begin{array}{l}\text { Panel Fixed and Ran- } \\
\text { dom Effects }\end{array}$ & $\begin{array}{l}\text { There is an increasing linear rela- } \\
\text { tionship between GDP and CO2 } \\
\text { emissions. }\end{array}$ \\
\hline $\begin{array}{l}\text { Sarisoy } \\
\& \text { Yildız } \\
(2013) \\
\end{array}$ & $\begin{array}{l}\text { 1992-2009 } \\
\text { annually }\end{array}$ & 30 countries & $\begin{array}{l}\text { Panel Fixed Effects } \\
\text { and Granger Cau- } \\
\text { sality }\end{array}$ & $\begin{array}{l}\mathrm{CO} 2 \text { emissions increase with the rise } \\
\text { in income. }\end{array}$ \\
\hline $\begin{array}{l}\text { Dal et al. } \\
(2013)\end{array}$ & $\begin{array}{l}\text { 1960-2010 } \\
\text { annually }\end{array}$ & Turkey & DOLS & $\begin{array}{l}\text { Economic growth increases carbon } \\
\text { emissions in long run. }\end{array}$ \\
\hline $\begin{array}{l}\text { Ayşe \& } \\
\text { Zeren (2011) }\end{array}$ & $\begin{array}{l}\text { 2000-2005 } \\
\text { annually }\end{array}$ & $\begin{array}{l}17 \text { Mediterranean } \\
\text { countries }\end{array}$ & $\begin{array}{l}\text { Fixed and Random } \\
\text { Effect Models }\end{array}$ & $\begin{array}{l}\text { Economic growth makes carbon } \\
\text { emissions increased. }\end{array}$ \\
\hline Aşıcı (2013) & $\begin{array}{l}\text { 1970-2008 } \\
\text { annually }\end{array}$ & 213 countries & $\begin{array}{l}\text { Panel Fixed-Ef- } \\
\text { fects Instrumental } \\
\text { Variable }\end{array}$ & $\begin{array}{l}\text { Income per capita has positive } \\
\text { relationship with per capita pressure } \\
\text { on nature. }\end{array}$ \\
\hline $\begin{array}{l}\text { Boopen } \\
\text { \& Vinesh } \\
(2011)\end{array}$ & $\begin{array}{l}\text { 1975-2009 } \\
\text { annually }\end{array}$ & Mauritian & $\begin{array}{l}\text { Ordinary Least } \\
\text { Squares (OLS), De- } \\
\text { composition-Based } \\
\text { Vector Autoregres- } \\
\text { sive }\end{array}$ & $\begin{array}{l}\text { Economic and human activities have } \\
\text { increasingly negative environmental } \\
\text { impacts on the country. }\end{array}$ \\
\hline $\begin{array}{l}\text { Roca et al. } \\
(2001)\end{array}$ & $\begin{array}{l}\text { 1973-1996 } \\
\text { annually }\end{array}$ & Spain & $\begin{array}{l}\text { Seemingly Unrelated } \\
\text { Regression }\end{array}$ & $\begin{array}{l}\text { Economic growth increased economic } \\
\text { pollutants. }\end{array}$ \\
\hline
\end{tabular}

\section{Source: Own preparation.}


Table 2.

Definitions of variables

\begin{tabular}{lll}
\hline Variable Name & Abbreviations & \multicolumn{1}{c}{ Explanation of variables } \\
\hline $\begin{array}{l}\text { CO2 emission } \\
\text { per capita }\end{array}$ & LCO & $\begin{array}{l}\text { This variable is calculated as the natural logarithm of the carbon dioxide } \\
\text { emissions per capita of the countries. Carbon dioxide emissions per capita are } \\
\text { obtained by dividing the annual total carbon dioxide emission data of the coun- } \\
\text { tries by the population. The unit of measure is tons. } \\
\text { This variable was calculated by taking the natural logarithm of GDP per capita. } \\
\text { (2010, USA Dollar). }\end{array}$ \\
$\begin{array}{l}\text { economic } \\
\text { growth rate }\end{array}$ & LGDPC &
\end{tabular}

Source: Own preparation based on Ritchie \& Roser (2020), World Bank (2021).

Table 3.

Countries covered

\begin{tabular}{|c|c|c|c|c|c|}
\hline No & Countries & No & Countries & No & Countries \\
\hline 1 & Albania & 18 & Guyana & 35 & Oman \\
\hline 2 & Algeria & 19 & Indonesia & 36 & Pakistan \\
\hline 3 & Azerbaijan & 20 & Iranian & 37 & Saudi Arabia \\
\hline 4 & Bahrain & 21 & Iraq & 38 & Senegal \\
\hline 5 & Bangladesh & 22 & Jordan & 39 & Sierra Leone \\
\hline 6 & Benin & 23 & Kazakhstan & 40 & Suriname \\
\hline 7 & Brunei & 24 & Kuwait & 41 & Tajikistan \\
\hline 8 & Burkina Faso & 25 & Kyrgyz Republic & 42 & Togo \\
\hline 9 & Cameroon & 26 & Lebanon & 43 & Tunisia \\
\hline 10 & Chad & 27 & Malaysia & 44 & Turkey \\
\hline 11 & Comoros & 28 & Maldives & 45 & Turkmenistan \\
\hline 12 & Ivory Coast & 29 & Mali & 46 & Uganda \\
\hline 13 & Egypt & 30 & Mauritania & 47 & UAE \\
\hline 14 & Gabon & 31 & Morocco & 48 & Uzbekistan \\
\hline 15 & Gambia & 32 & Mozambique & 49 & West Bank and Gaza \\
\hline 16 & Guinea & 33 & Niger & 50 & Yemen \\
\hline 17 & Guinea-Bissau & 34 & Nigeria & & \\
\hline
\end{tabular}

Source: Own preparation. 
Table 4.

Summary statistics

\begin{tabular}{lrr}
\hline \multicolumn{1}{c}{ Statistics } & \multicolumn{1}{c}{ LCO } & \multicolumn{1}{c}{ LGDPC } \\
\hline average & 0.160905 & 7.769830 \\
median & 0.321890 & 7.624422 \\
maximum & 3.567640 & 11.08006 \\
minimum & -4.154016 & 5.371408 \\
standard deviation & 1.780777 & 1.320297 \\
skewness & -0.042330 & 0.538677 \\
kurtosis & 2.066902 & 2.436554 \\
Jarque-Bera & 42.06309 & 70.82862 \\
number of observations & 1150 & 1150 \\
\hline
\end{tabular}

Source: Own preparation.

Table 5.

Pesaran (2004) CD test results

\begin{tabular}{lcccc}
\hline \multicolumn{1}{c}{ Variable } & CD-test & P-value & Correlation & Absolute (correlation) \\
\hline LCO & 45.79 & 0.000 & 0.273 & 0.519 \\
LGDPC & 71.40 & 0.000 & 0.425 & 0.693 \\
\hline
\end{tabular}

Note:

$\mathrm{H}_{0}$ hypothesis express that there is no cross-sectional dependency, $\mathrm{CD} \sim \mathrm{N}(0,1)$.

Source: Own preparation.

Table 6.

CIPS unit root test results

\begin{tabular}{|c|c|c|c|c|c|c|c|c|}
\hline \multirow{3}{*}{ Variable } & \multicolumn{4}{|c|}{ Levels values } & \multicolumn{4}{|c|}{ First differences } \\
\hline & \multicolumn{3}{|c|}{ critical values } & \multirow{2}{*}{$\begin{array}{c}\text { CIPS test } \\
\text { statistic }\end{array}$} & \multicolumn{3}{|c|}{ critical values } & \multirow{2}{*}{$\begin{array}{c}\text { CIPS test } \\
\text { statistic }\end{array}$} \\
\hline & $1 \%$ & $5 \%$ & $10 \%$ & & $1 \%$ & $5 \%$ & $10 \%$ & \\
\hline \multicolumn{9}{|c|}{ with constant } \\
\hline $\begin{array}{c}\text { LCO } \\
\text { LGDPC }\end{array}$ & -2.23 & -2.11 & -2.04 & $\begin{array}{l}-2.20 \\
-1.89 \\
\end{array}$ & -2.23 & -2.11 & -2.04 & $\begin{array}{l}-4.51 \\
-3.74 \\
\end{array}$ \\
\hline \multicolumn{9}{|c|}{ with constant and trend } \\
\hline $\begin{array}{c}\text { LCO } \\
\text { LGDPC }\end{array}$ & -2.73 & -2.61 & 2.54 & $\begin{array}{r}-2.22 \\
-1.91\end{array}$ & -2.73 & -2.61 & 2.54 & $\begin{array}{l}-4.51 \\
-3.92\end{array}$ \\
\hline
\end{tabular}

Note:

The lag length was determined by the F-test according to the general to specific method.

$\mathrm{H}_{0}$ : The series is not stationary.

Source: Own preparation. 
Table 7.

Panel Westerlund and Pedroni cointegration tests

\begin{tabular}{lrrrrrrrrr}
\hline & \multicolumn{7}{c}{ Westerlund } & & \multicolumn{7}{c}{ Pedroni } \\
Statistics & Value & Z-value & p-value & Statistics & Value & p-value & Statistics & Value & p-value \\
\hline$G_{t}$ & -3.16 & -10.89 & 0.000 & panel v & 1.96 & 0.025 & group rho & -1.30 & 0.096 \\
$G_{a}$ & -8.62 & -1.86 & 0.031 & panel rho & -3.05 & 0.001 & group PP & -4.71 & 0.000 \\
$P_{t}$ & -17.7 & -7.25 & 0.000 & panel PP & -4.40 & 0.000 & group ADF & -4.57 & 0.000 \\
$P_{a}$ & -9.18 & -0.441 & 0.000 & panel ADF & -4.84 & 0.000 & - & - & - \\
\hline
\end{tabular}

Source: Own preparation.

Table 8.

Granger and Dumitrescu-Hurlin causality analysis results

\begin{tabular}{lccc}
\hline \multicolumn{1}{c}{ Null Hypothesis } & $\begin{array}{c}\text { Granger } \\
\text { Observations }\end{array}$ & F-statistic & Probability \\
\hline LGDPC is not Granger cause of LCO. & 1050 & 6.23769 & 0.002 \\
LCO is not Granger cause of LGDPC. & Dumitrescu-Hurlin & & 0.000 \\
\hline & W-statistic & Zbar-statistic & Probability \\
Null Hypothesis & 4.80399 & 6.74677 & 0.000 \\
\hline LGDPC is not homogeneously cause of LCO. & 3.36913 & 2.90262 & 0.003 \\
LCO is not homogeneously cause of LGDPC. & & & \\
\hline
\end{tabular}

Source: Own preparation.

Table 9.

PMGE and MGE analysis results for all countries

\begin{tabular}{|c|c|c|c|c|}
\hline \multicolumn{5}{|c|}{ Model: $L_{C O}{ }_{i t}=\beta_{0}+\beta_{1} G D P C_{i t}+u_{i t}$} \\
\hline Period & Variables & Coefficients & Standard errors & p-value \\
\hline \multicolumn{5}{|c|}{ PMGE } \\
\hline long-run & $L_{G D P C}$ & 0.6609 & 0.0368 & 0.000 \\
\hline \multirow[t]{3}{*}{ short-run } & ec & -0.2765 & 0.0281 & 0.000 \\
\hline & $L_{G D P C}$ & 0.4339 & 0.1059 & 0.000 \\
\hline & constant & -1.360 & 0.1465 & 0.000 \\
\hline \multicolumn{5}{|c|}{ MGE } \\
\hline long-run & $L_{G D P C}$ & 0.8941 & 0.2247 & 0.000 \\
\hline \multirow[t]{3}{*}{ short-run } & ec & -0.4166 & 0.0288 & 0.000 \\
\hline & $L_{G D P C}$ & 0.3398 & 0.1035 & 0.001 \\
\hline & constant & -2.882 & 0.4982 & 0.000 \\
\hline
\end{tabular}

Source: Own preparation. 
Table 10.

Hausman test results for long-term homogeneity

\begin{tabular}{ccccc}
\hline Variable & $(\mathrm{b})$ & $(\mathrm{B})$ & $(\mathrm{b}-\mathrm{B})$ & $\operatorname{sqrt}\left(\operatorname{diag}\left(\mathrm{V}_{\mathrm{b}}-\mathrm{V}_{\mathrm{B}}\right)\right.$ \\
& $\mathrm{MG}$ & $\mathrm{PMG}$ & Difference & S.E. \\
\hline LGDPC $_{\mathrm{it}}$ & 0.8941 & 0.6609 & 0.2333 & 0 \\
\hline
\end{tabular}

Notes:

b: consistent under $\mathrm{H}_{0}$ and $\mathrm{H}_{\mathrm{a}}$, obtained from MGE.

B: inconsistent under $\mathrm{H}_{\mathrm{a}}$, efficient under $\mathrm{Ho}$, obtained from PMGE.

$\mathrm{H}_{0}$ : difference in coefficients not systematic.

$\operatorname{chi}^{2}(1)=(b-B)^{\prime}\left[\left(V_{b}-V_{B}\right)^{-1}\right](b-B)=0.91$.

Prob $>\mathrm{chi}^{2}=0.3399$.

Source: Own preparation.

Table 11.

PMGE and MGE analysis results

\begin{tabular}{|c|c|c|c|c|c|c|c|}
\hline \multicolumn{8}{|c|}{ Model: $L C O_{i t}=\beta_{0}+\beta_{1} G D P C_{i t}+u_{i t}$} \\
\hline \multirow{3}{*}{ ID } & \multirow{3}{*}{ Countries } & \multicolumn{3}{|c|}{ PMGE } & \multicolumn{3}{|c|}{ MGE } \\
\hline & & $\begin{array}{l}\text { Long-run } \\
\text { coefficient }\end{array}$ & $\begin{array}{l}\text { Short-run } \\
\text { coefficient }\end{array}$ & Short-run & $\begin{array}{l}\text { Long-run } \\
\text { coefficient }\end{array}$ & $\begin{array}{l}\text { Short-run } \\
\text { coefficient }\end{array}$ & Short-run \\
\hline & & $L_{G D P C}$ & $L_{G D P C}$ & & $L_{G D P C}$ & $L_{G D P C}$ & ec \\
\hline 1 & Albania & $1.8259^{* * *}$ & -0.1213 & $1.2205^{* * *}$ & $1.6178^{* * *}$ & $-0.4475^{* * *}$ & $1.8259^{* * *}$ \\
\hline 2 & Algeria & 1.0283 & $-0.3701^{* *}$ & 1.1027 & 1.5938 & -0.2710 & 1.0283 \\
\hline 3 & Azerbaijan & 0.0492 & -0.0471 & 0.0251 & 0.1308 & $-0.8106^{* * *}$ & 0.0492 \\
\hline 4 & Bahrain & $2.4092^{* *}$ & $-0.3857^{* *}$ & 1.0182 & $2.3292^{*}$ & $-0.3930^{* *}$ & $2.4092^{* *}$ \\
\hline 5 & Bangladesh & 1.0759 & -0.0524 & $1.3140^{* * *}$ & -0.5472 & $-0.5427^{* *}$ & 1.0759 \\
\hline 6 & Benin & 0.9211 & -0.0316 & $5.1912^{* * *}$ & -0.0126 & $-0.2719^{*}$ & 0.9211 \\
\hline 7 & Brunei & -0.9961 & -0.1817 & -1.8341 & -0.776 & -0.2561 & -0.9961 \\
\hline 8 & Burkina Faso & 0.7221 & -0.0579 & $1.7362^{* * *}$ & 0.3008 & $-0.3872^{* *}$ & 0.7221 \\
\hline 9 & Cameroon & -0.1735 & $-0.3703^{* *}$ & $1.8128^{* *}$ & -0.5399 & $-0.4131^{* * *}$ & -0.1735 \\
\hline 10 & Chad & 0.2777 & $-0.2627^{* *}$ & $1.4225^{* * *}$ & 0.0496 & $-0.9347^{* * *}$ & 0.2777 \\
\hline 11 & Comoros & 1.2459 & $-0.5727^{* * *}$ & $2.1848^{* *}$ & 0.3863 & $-0.7192^{* * *}$ & 1.2459 \\
\hline 12 & Ivory Coast & $1.4576^{* *}$ & $-0.6736^{* * *}$ & $1.0080^{* *}$ & 1.1794 & $-0.7548^{* * *}$ & $1.4576^{* *}$ \\
\hline 13 & Egypt & $1.3540^{* *}$ & $-0.3787^{* * *}$ & $0.6781^{* * *}$ & $1.3744^{*}$ & $-0.3855^{* *}$ & $1.3540^{* *}$ \\
\hline 14 & Gabon & $0.6305^{* *}$ & -0.0819 & $1.6615^{* * *}$ & 0.4300 & -0.2148 & $0.6305^{* *}$ \\
\hline 15 & Gambia & -0.2279 & -0.0143 & -3.8922 & -0.1544 & -0.0372 & -0.2279 \\
\hline 16 & Guinea & 0.1773 & $-0.2658^{* *}$ & 0.5163 & 0.2786 & $-0.2571^{*}$ & 0.1773 \\
\hline 17 & Guinea-Bissau & 0.1952 & $-0.4252^{* *}$ & 0.4095 & 0.2353 & $-0.4462^{* *}$ & 0.1952 \\
\hline 18 & Guyana & 0.6648 & $-0.3527^{* *}$ & $0.6106^{* * *}$ & 0.6554 & $-0.3687^{*}$ & 0.6648 \\
\hline 19 & Indonesia & $1.4181^{* * *}$ & $-0.4349^{* * *}$ & 0.3863 & $1.6307^{* * *}$ & $-0.3814^{* *}$ & $1.4181^{* * *}$ \\
\hline 20 & Iranian & -0.2122 & $-0.1517^{*}$ & $1.0770^{* * *}$ & -0.2799 & -0.2434 & -0.2122 \\
\hline 21 & Iraq & 0.0653 & $-0.3790^{* *}$ & 0.6524 & 0.0657 & $-0.3804^{* *}$ & 0.0653 \\
\hline 22 & Jordan & 0.8444 & 0.0363 & -4.3485 & 0.9182 & -0.0228 & 0.8444 \\
\hline 23 & Kazakhstan & 0.1497 & $-0.5776^{* * *}$ & $0.6163^{* * *}$ & -0.0222 & $-0.6561^{* * *}$ & 0.1497 \\
\hline 24 & Kuwait & -0.1417 & $-0.6106^{* * *}$ & $0.6064^{* * *}$ & -0.1289 & $-0.6282^{* * *}$ & -0.1417 \\
\hline
\end{tabular}




\begin{tabular}{|c|c|c|c|c|c|c|c|}
\hline \multicolumn{8}{|c|}{ Model: $L C O_{i t}=\beta_{0}+\beta_{1} G D P C_{i t}+u_{i t}$} \\
\hline \multirow{3}{*}{ ID } & \multirow{3}{*}{ Countries } & \multicolumn{3}{|c|}{ PMGE } & \multicolumn{3}{|c|}{ MGE } \\
\hline & & $\begin{array}{l}\text { Long-run } \\
\text { coefficient }\end{array}$ & $\begin{array}{l}\text { Short-run } \\
\text { coefficient }\end{array}$ & & $\begin{array}{l}\text { Long-run } \\
\text { coefficient }\end{array}$ & $\begin{array}{l}\text { Short-run } \\
\text { coefficient }\end{array}$ & \\
\hline & & $L_{G D P C}$ & $L_{G D P C}$ & $e c$ & $L_{G D P C}$ & $\mathrm{LGDPC}_{i t}$ & ec \\
\hline 25 & Kyrgyz Republic & 0.3103 & $-0.3748^{* *}$ & $0.9538^{* * *}$ & 0.4060 & $-0.4222^{* *}$ & 0.3103 \\
\hline 26 & Lebanon & $0.8259^{*}$ & -0.0890 & 0.8149 & 0.8292 & -0.0838 & $0.8259^{*}$ \\
\hline 27 & Malaysia & $0.6057^{*}$ & $-0.4090^{* *}$ & $0.8203^{* * *}$ & 0.4469 & $-0.5081^{* * *}$ & $0.6057^{*}$ \\
\hline 28 & Maldives & 0.3689 & -0.1347 & $2.1997^{* * *}$ & -0.2782 & $-0.5470^{* * *}$ & 0.3689 \\
\hline 29 & Mali & 0.8289 & $-0.4439^{* *}$ & 0.6136 & 0.8199 & $-0.4413^{* *}$ & 0.8289 \\
\hline 30 & Mauritania & -0.3203 & -0.0899 & $1.4538^{* * *}$ & $-0.5111^{* *}$ & $-0.2642^{* *}$ & -0.3203 \\
\hline 31 & Morocco & 0.0870 & -0.2201 & $0.8325^{* * *}$ & 0.0887 & -0.3681 & 0.0870 \\
\hline 32 & Mozambique & -0.8307 & -0.0157 & 3.0220 & 0.3966 & -0.1412 & -0.8307 \\
\hline 33 & Niger & $1.6128^{* *}$ & -0.0706 & $5.2092^{* * *}$ & 0.5913 & $-0.2519^{* *}$ & $1.6128^{* *}$ \\
\hline 34 & Nigeria & 1.2926 & $-0.2713^{*}$ & -0.1516 & 1.2287 & $-0.2811^{*}$ & 1.2926 \\
\hline 35 & Oman & $-1.1773^{*}$ & $-0.1767^{* *}$ & 3.9090 & $-1.5162^{*}$ & $-0.1797^{* *}$ & $-1.1773^{*}$ \\
\hline 36 & Pakistan & $1.0526^{* * *}$ & $-0.2850^{* * *}$ & $0.5776^{* *}$ & $1.1177^{* * *}$ & $-0.2622^{* *}$ & $1.0526^{* * *}$ \\
\hline 37 & Saudi Arabia & 0.3660 & -0.1748 & 1.0356 & 0.3329 & -0.1922 & 0.3660 \\
\hline 38 & Senegal & 1.1062 & $-0.4438^{* *}$ & $1.3932^{* * *}$ & 0.4785 & $-0.5496^{* * *}$ & 1.1062 \\
\hline 39 & Sierra Leone & 0.0583 & -0.1661 & $1.4130^{* *}$ & -0.0740 & -0.2323 & 0.0583 \\
\hline 40 & Suriname & -0.1049 & $-0.1926^{*}$ & -0.2495 & -0.4297 & $-0.4396^{* *}$ & -0.1049 \\
\hline 41 & Tajikistan & -0.8504 & $-0.3146^{* * *}$ & $0.7828^{*}$ & -0.8618 & $-0.2887^{*}$ & -0.8504 \\
\hline 42 & Togo & -0.4134 & $-0.6531^{* * *}$ & 0.8221 & -0.5285 & $-0.6520^{* * *}$ & -0.4134 \\
\hline 43 & Tunisia & $0.7165^{* *}$ & $-0.5886^{* * *}$ & $0.6084^{* * *}$ & 0.5012 & $-0.6689^{* * *}$ & $0.7165^{* *}$ \\
\hline 44 & Turkey & $0.4124^{* *}$ & $-0.3492^{* *}$ & $0.7528^{* * *}$ & 0.3159 & $-0.4133^{* *}$ & $0.4124^{* *}$ \\
\hline 45 & Turkmenistan & 0.3313 & -0.0686 & $0.3871^{* * *}$ & $0.4974^{*}$ & $-0.5144^{* *}$ & 0.3313 \\
\hline 46 & Uganda & 0.3545 & -0.0424 & $1.6713^{* * *}$ & -0.1163 & $-0.5610^{* * *}$ & 0.3545 \\
\hline 47 & UAE & 0.0997 & $-0.5540^{* * *}$ & 0.2848 & 0.0962 & $-0.6629^{* * *}$ & 0.0997 \\
\hline 48 & Uzbekistan & -0.729 & 0.0186 & $-0.5278^{* * *}$ & 1.3680 & $-0.7409^{* * *}$ & -0.729 \\
\hline 49 & West Bank and Gaza & 0.6508 & $-0.4005^{* *}$ & 0.3004 & 0.7383 & $-0.4021^{* *}$ & 0.6508 \\
\hline 50 & Yemen & 0.2790 & $-0.5494^{* * *}$ & $0.6024^{*}$ & 0.3377 & $-0.5388^{* * *}$ & 0.279 \\
\hline
\end{tabular}

Note:

${ }^{* * *} \mathrm{p}<0.01,{ }^{* *} \mathrm{p}<0.05,{ }^{*} \mathrm{p}<0.1$.

Source: Own preparation. 
